\title{
Evaluation of the Physico-Chemical Properties of Soil and Apple Leaves (Malus Domestica) in Beni Mellal- Khenifra Region, Morocco
}

\author{
Berrid Nabyl ${ }^{1}$, Lougraimzi Hanane ${ }^{2}$, El-Khabbazi Houda ${ }^{3}$, Abidli Zakaria ${ }^{3}$, Hamidi Otman ${ }^{1}$, Keltoum Rahali $^{1}$, El Mahjoub Aouane ${ }^{1, *}$ \\ ${ }^{1}$ Laboratory of Biotechnology, Quality and Environment, Faculty of Science, Ibn Tofail, University, Kenitra, Morocco \\ ${ }^{2}$ Laboratory of Nutrition, Health and Environment, Faculty of Sciences, Ibn Tofail University, Kenitra, Morocco \\ ${ }^{3}$ Laboratory of Genetic and Biometric, Faculty of Sciences, Ibn Tofail University, Kenitra, Morocco
}

\begin{tabular}{l} 
A R T I C L E I N F O \\
\hline Article history: \\
Received: 01 September, 2020 \\
Accepted: 26 November, 2020 \\
Online: 14 December, 2020
\end{tabular}

Keywords:

Physico-chemical properties

Soil

Apple leaves

Mineral elements

Organic matter

Morocco

\begin{abstract}
A B S T R A C T
The apple tree (Malus domestica) is an agricultural species of great importance in Morocco. Currently, it occupies about a quarter of the surface of fruit-bearing rosaceae. Apple tree production has evolved rapidly, stimulated by a buoyant market, a varietal range which is tending to diversify and a dynamic profession. The present study aims to determine the physico-chemical properties of soil and apple leaves in Beni Mellal-Khenifra region, Morocco. Data collection was consisted to sample the soils at different depths, three Pearson correlation coefficients were determined: i) Correlation between organic matter and soil mineral elements, ii) Correlation between clay content and soil mineral elements and correlation between $\mathrm{CaCO} 3$ content and soil mineral elements. The analytical results of soils were compared to reference values. The results show that there is no correlation between these mineral elements and the rate of $\mathrm{CaCO} 3$ and clay fraction. Analysis of the main components showed that the apple leaf contains more sodium, copper and zinc and less magnesium, phosphorus and potassium. The coefficient of variation $(\mathrm{CV})$ of manganese content expressed as a percentage is significantly higher than that of the other elements, while the potassium content is the lowest, in particular for magnesium and sodium the coefficient of variation is zero. In apple orchards in the Middle Atlas, there are great variations in terms of yield levels, fertilizer inputs, soil richness in nutrients and their concentration at leaf level. These variations are due to differences in cultivation practices, in particular fertilization, because the relationship between apple yield and nutrient content at soil and leaf level is significant.
\end{abstract}

\section{Introduction}

The agricultural sector plays a key role in economic activities in Morocco. Likewise, it represents a strong support to the development of the country because it constitutes a higher percentage of $20 \%$ of the gross domestic product and employs about $40 \%$ of the active population $[1,2]$.

In Morocco, the apple tree (Malus domestica) is the species, which occupies the largest surface in terms of fruit rosaceae. Currently, orchards planted with apples total 32,000 ha, or about a quarter of the surface area of fruit-bearing rosaceae. Annual production is estimated at 560-600,000 tonnes, based on an

${ }^{*}$ Corresponding Author, El Mahjoub Aouane, University Campus BP 133 Kenitra, Morocco. Email: aouane_mahjoub@yahoo.fr average yield of around $20 \mathrm{~T} / \mathrm{ha}$ [3]. However, Intensive agriculture and the search for new fertile land put pressure on the ecosystem, which in turn leads to reduced soil fertility $[4,5]$. As a result, yields are relatively low and land productivity decreases. There are several types of soils in Morocco which have developed on different geological substrates and in various climatic, topographical and biotic contexts. These soils must be protected as a natural resource because it contains substances essential to the maintenance of ecosystems and human populations, such as essential minerals. this study is carried out in the Beni MellalKhenifra region which is characterized by a variety of soils and by the predominance of fertile types rich in organic matter which allows an important agricultural activity, in particular for apple trees [6]. So far, interpretation of soil and leaf analyzes for 
Moroccan apple orchards has been limited. For this reason, the main objective of our study is to determine the physicochemical properties of soil analysis and apple leaves in the Beni MellalKhenifra region in Morocco. More specifically, i) Determining the correlation coefficients between organic matter and soil mineral elements, ii) Correlation between clay content and soil mineral elements and correlation between $\mathrm{CaCO} 3$ content and soil mineral elements.

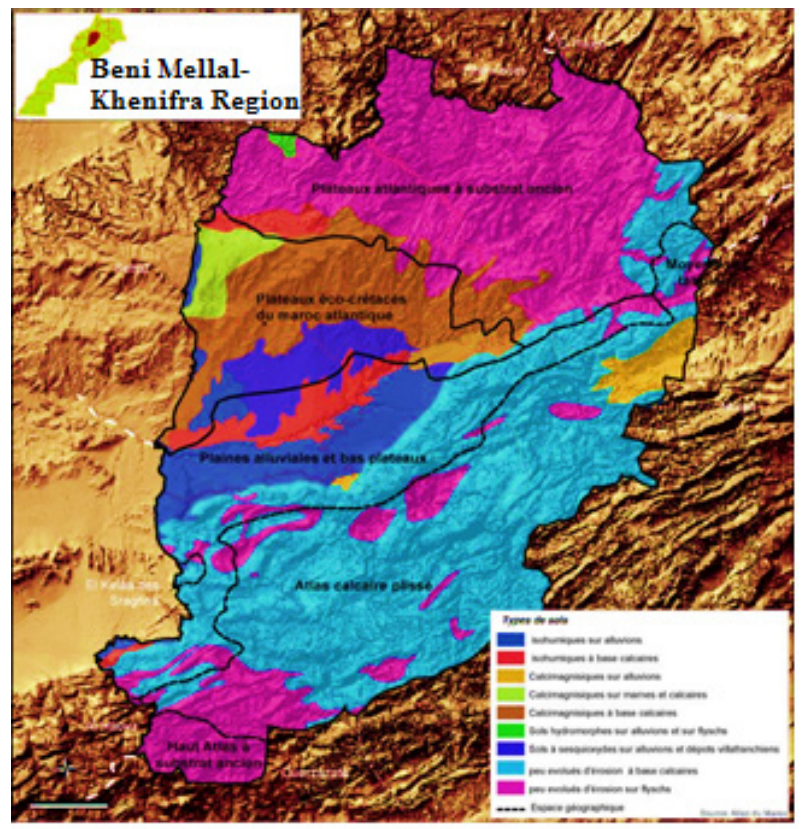

Figure 1: Geographical location and soil types in Beni Mellal-Khenifra region,

\section{Materials and methods} study site [7]

\subsection{Presentation of the study area}

The Beni Mellal-Khenifra region is a major contributor to national agriculture. From field crops to local products, its environmental diversity allows it to have a very varied agriculture. Between mountains, foothills and plains, the diversity of climates and soils offers the Beni Mellal-Khenifra region many agricultural opportunities. In addition to its environmental and natural wealth, this region has the advantage of having significant water resources unlike other regions of the Kingdom. The study area is part of the perimeter of the Beni Mellal-Khenifra region, which is made up of four large distinct geographic areas, which maintain relations of exchange, complementarity and forms of solidarity, particularly in the field of agriculture and extensive farming [7]. It has a total surface area of 2.8 million hectares, of which 960,000 hectares of useful agricultural area $(205,000$ hectares under irrigation and 700,000 hectares of rangelands). Moreover, the region has adopted a specific agricultural plan designed to remove the constraints that hamper agricultural development. It is a specific region, inserted between the Atlas Mountains and the Atlantic coastal provinces, with a much-contrasted physiognomy and a marked character. However, these contrasts, however clear-cut they may appear, present undeniable advantages for the implementation of mutually beneficial solidarity, the rich natural heritage (hydraulic and forest) which is highly diversified, the agricultural potential of the plain which is being reconverted (Beni Amir and Beni Moussa), the opportunities offered by mining activity, the major structuring projects (connecting infrastructures and agro-industrial and commercial platforms) and the hinge position in the national system [7].

\subsection{Soil types in the area}

The soils in the region are diverse due to the nature of the source rocks. They are shallow, shallow, and low in humus. Their water reserves are sometimes limited. Moreover, the dominance of holm oak, a very plastic species from an ecological point of view, confirms this situation when the ecological atmosphere is difficult. The substrates are colonized by thermo-xerophilic (Aleppo pine, thuja and red juniper) and xerophilic (Thuriferous juniper) species (Figure 1). Even at altitude, the soils generally remain shallow to shallow, humus and humid for a fairly long period of the year, allowing the establishment of friendly forest species (zene oak, cedar and holm oak) [7].

\subsection{Soil sample collection}

The study covered 19 observation sites (10 samples by site). Soil samples were taken at different depths $(0-60 \mathrm{~cm})$ using an auger on plots of apples. These samples were air dried overnight or longer and sieved through a $2 \mathrm{~mm}$ sieve to obtain a fine soil. The results of the soil analyzes were compared to limit values and reference standards. We also measured the electrical conductivity and $\mathrm{pH}$ of the main elements using the same techniques as below:

Table 1: Analysis technique.

\begin{tabular}{|c|c|}
\hline Analysis & Methods \\
\hline Granulometry & $\begin{array}{c}\text { Sieving }(2 \mathrm{~mm} \text { to } 45 \mu \mathrm{m} \\
\text { sieve })\end{array}$ \\
\hline $\mathrm{pH} 1 / 2.5$ & $\mathrm{pH}$ to put \\
\hline $\mathrm{CE} 1 / 525^{\circ} \mathrm{C}$ & Granulometry \\
\hline $\begin{array}{c}\text { Cation exchange capacity } \\
\mathrm{CEC} \text { and exchangeable } \\
\text { shares }\end{array}$ & $\begin{array}{c}\text { Cationic exchange capacity } \\
\text { CEC and exchangeable } \\
\text { shares }\end{array}$ \\
\hline $\mathrm{Na}+$ and $\mathrm{K}+$ Cations & Flame spectrophotometer \\
\hline $\mathrm{Ca}++$ and $\mathrm{Mg}++$ Cations & Volumetric titration \\
\hline Chlorides Cl- & $\begin{array}{c}\text { MOHR method (silver } \\
\text { nitrate precipitation in the } \\
\text { presence of chromates })\end{array}$ \\
\hline Sulphate SO4-- & Precipitation at BaCl2 \\
\hline
\end{tabular}

\subsection{Sampling of plant material}

The foliar analysis of the apple tree (or foliar diagnosis of the apple tree), is the best way to determine the quantity and the type of fertilizer to give to the fruit trees. Thirty samples of healthy and homogeneous trees were chosen (70 to 90 days after full flowering (stage F2)) and the samples were representative of the plot. We chose the woody branches representative of the vigor and the average growth of the tree (eliminate the greedy ones), the leaf in the middle of the branch with its stem.

In total 200 sheets. The collected leaves are placed in new perforated plastic bags and awaiting transport to the analysis 
laboratory; they are stored cool or cold at $4-5^{\circ} \mathrm{C}$ so that they retain all their characteristics. The analysis is carried out the day after harvest at the latest. It focuses in particular on the nitrogen content expressed as a percentage of dry matter (\% DM). The results of soil analyzes were compared to values thresholds and reference standards specific to apple production (Table 2).

Table 2: Reference thresholds [8].

\begin{tabular}{|c|c|c|c|c|c|}
\hline & $\begin{array}{c}\mathrm{N}(\% \\
\mathrm{MS})\end{array}$ & $\begin{array}{l}\mathrm{P}(\% \\
\mathrm{MS})\end{array}$ & $\begin{array}{c}\mathrm{K}(\% \\
\mathrm{MS})\end{array}$ & $\begin{array}{c}\mathrm{Ca}(\% \\
\mathrm{MS})\end{array}$ & $\begin{array}{c}\mathrm{Mg}(\% \\
\mathrm{MS})\end{array}$ \\
\hline Apple & $2.2-2.4$ & 0.22 & $\begin{array}{c}1.13 \mathrm{à} \\
1.75\end{array}$ & 1.25 & $\begin{array}{c}0.22 \mathrm{à} \\
0.3\end{array}$ \\
\hline Prunes & $2.4-3$ & $\begin{array}{c}0.14- \\
0.25\end{array}$ & $1.6-3$ & $1.5-3$ & $\begin{array}{c}0.3- \\
0.8\end{array}$ \\
\hline
\end{tabular}

\subsection{Statistical methodology}

Statistical analysis was performed using SPSS software. Descriptive statistics were used and analyzes of variance and comparison of means were performed at a probability level of $\mathrm{p}<0.05$.

\section{Results}

\subsection{Physico-chemical characteristics of the soil studied for each site}

The results of the particle size analysis of the studied soils are presented in table 3. On the samples analyzed, the texture tests did not reveal significant clay contents except for site 2 , which showed values barely greater than $45 \%$. The clay content of the studied soils varies between $26 \%$ and $46.57 \%$. Under these conditions, the deep migration of nutrients is slow and leaching losses are low. According to the Texture Triangle (FAO), which is used to determine the textural class of soils, the study area mainly has loamy clay soils. Considering also that apple trees prefer healthy and deep loamy-clayey-loamy soils with a permeable subsoil, it can be assumed that the studied soils are favorable for this apple crop.

Table 3: Physical constituents of the soils studied.

\begin{tabular}{|c|c|c|c|c|}
\hline \multirow{2}{*}{$\begin{array}{l}\text { Observation } \\
\text { sites }\end{array}$} & \multirow{2}{*}{ Depth } & \multicolumn{3}{|c|}{ Granulometry (\%) } \\
\cline { 3 - 5 } & $20-50$ & 35 & 30 & 35 \\
\hline 1 & $0-20$ & 35 & 30 & 35 \\
\hline 2 & $0-20$ & 45 & 25 & 30 \\
\hline 3 & $20-50$ & 45 & 30 & 25 \\
\hline 4 & $30-60$ & 26 & 18.77 & 55.23 \\
\hline 5 & $0-30$ & 40.73 & 25.98 & 33.29 \\
\hline 6 & $30-60$ & 39.91 & 26.1 & 33.99 \\
\hline 7 & $0-30$ & 26.92 & 47.52 & 25.56 \\
\hline 8 & $30-60$ & 27.13 & 46.69 & 26.18 \\
\hline 9 & $0-30$ & 31.97 & 39.2 & 28.83 \\
\hline 10 & $30-60$ & 32.1 & 38.99 & 28.91 \\
\hline 11 & $0-30$ & 44.81 & 43.24 & 11.95 \\
\hline 12 & $30-60$ & 45.02 & 43.45 & 11.53 \\
\hline 13 & $0-30$ & 46.49 & 42.54 & 10.97 \\
\hline 14 & $30-60$ & 46.96 & 41.99 & 11.05 \\
\hline 15 & & & &
\end{tabular}

\begin{tabular}{|c|c|c|c|c|}
\hline 16 & $0-30$ & 40.46 & 35.71 & 23.83 \\
\hline 17 & $30-60$ & 41 & 35.5 & 23.5 \\
\hline 18 & $40-60$ & 42.7 & 44.05 & 12.95 \\
\hline 19 & $0-40$ & 41 & 43.5 & 15.5 \\
\hline
\end{tabular}

The $\mathrm{pH}$ is an important parameter of soil dynamics, the degree of acidity or basicity plays a very essential role in the absorption of nutrients by the plant. The average $\mathrm{pH}$ of the soil samples studied is eight, which shows that the majority of sites are basic with an alkaline tendency (Table 4).

Table 4: General Statistics of different physico-chemical characteristics of the samples studies.

\begin{tabular}{|c|c|c|c|c|c|c|}
\hline \multirow{2}{*}{$\begin{array}{l}\text { Charact } \\
\text { eristics }\end{array}$} & \multirow[t]{2}{*}{ Min } & \multirow[t]{2}{*}{ Max } & \multirow{2}{*}{$\begin{array}{l}\text { Me } \\
\text { dian }\end{array}$} & \multicolumn{2}{|c|}{ Average } & \multirow{2}{*}{$\begin{array}{c}\begin{array}{c}\text { Standard } \\
\text { deviation }\end{array} \\
\begin{array}{c}\text { Statistiqu } \\
\mathrm{e}\end{array}\end{array}$} \\
\hline & & & & $\begin{array}{l}\text { Statis } \\
\text { tique }\end{array}$ & $\begin{array}{l}\text { Erreur } \\
\text { std }\end{array}$ & \\
\hline $\mathrm{MO}$ & $\begin{array}{c}0.4 \\
8\end{array}$ & 3 & 2.00 & 1.71 & .187 & 0.772 \\
\hline $\mathrm{pH}$ & 8 & 9 & 8.00 & 8.06 & .063 & 0.250 \\
\hline $\begin{array}{l}\mathrm{CaC} \\
\mathrm{O} 3\end{array}$ & 6 & 41 & $\begin{array}{c}10.0 \\
0\end{array}$ & 12.11 & 1.838 & 8.013 \\
\hline Clay & 26 & 47 & $\begin{array}{c}41.0 \\
0\end{array}$ & 38.58 & 1.596 & 6.955 \\
\hline Silt & 19 & 48 & $\begin{array}{c}37.5 \\
0\end{array}$ & 36.44 & 2.033 & 8.624 \\
\hline Sand & 12 & 55 & $\begin{array}{c}26.0 \\
0\end{array}$ & 26.11 & 2.567 & 10.889 \\
\hline $\begin{array}{l}\mathrm{Fe} \\
\mathrm{mg} / \mathrm{kg}\end{array}$ & 1 & 8 & 6.50 & 5.83 & .452 & 1.917 \\
\hline $\begin{array}{l}\mathrm{Bm} \\
\mathrm{g} / \mathrm{kg}\end{array}$ & 0 & 0 & 0.00 & 0.00 & 0.000 & 0.000 \\
\hline $\begin{array}{l}\mathrm{Zn} \\
\mathrm{mg} / \mathrm{kg}\end{array}$ & 0 & 6 & 3.00 & 2.72 & 0.523 & 2.218 \\
\hline $\begin{array}{l}\mathrm{Cu} \\
\mathrm{mg} / \mathrm{kg}\end{array}$ & 0 & 1 & 1.00 & 0.65 & 0.119 & 0.493 \\
\hline $\begin{array}{l}\mathrm{P} 2 \mathrm{O} 5 \\
\mathrm{mg} / \mathrm{kg}\end{array}$ & 2 & 47 & 5.00 & 10.40 & 2.953 & 11.438 \\
\hline $\begin{array}{l}\mathrm{K} 2 \mathrm{O} \\
\text { meq/10 } \\
0 \mathrm{~g}\end{array}$ & 0 & 551 & $\begin{array}{c}340 . \\
00\end{array}$ & $\begin{array}{c}301.9 \\
4\end{array}$ & 38.147 & 157.283 \\
\hline $\begin{array}{l}\mathrm{CaO} \\
\mathrm{meq} / 10 \\
0 \mathrm{~g}\end{array}$ & 12 & 6850 & $\begin{array}{c}138 \\
8.00\end{array}$ & $\begin{array}{c}3217 . \\
27\end{array}$ & $\begin{array}{c}689.23 \\
0\end{array}$ & 2669.376 \\
\hline $\begin{array}{l}\mathrm{MgO} \\
\mathrm{meq} / 10 \\
0 \mathrm{~g}\end{array}$ & 0 & 380 & $\begin{array}{c}320 . \\
00\end{array}$ & $\begin{array}{c}269.5 \\
3\end{array}$ & 36.272 & 140.479 \\
\hline
\end{tabular}

The soils studied exhibited an organic matter content in the range $0.48-3 \%$. Analysis of the elements of Iron, zinc and copper revealed average contents of $6.5 \mathrm{mg} / \mathrm{kg}, 3 \mathrm{mg} / \mathrm{kg}$ and $1 \mathrm{mg} / \mathrm{kg}$ respectively. For all the soils studied and sampled at different depths, three Pearson correlation coefficients were determined: one between the different soil types and $\mathrm{CaCO} 3$ content, the second between the different soil types and the percentage of organic matter, and the third between the different soil types and the clay content. The coefficients of determination obtained show 
that variation of soil types and their sampling at different depths explains $12 \%$ of the variation of clay content, $11 \%$ of $\mathrm{CaCO} 3$ and $8 \%$ of the material content. In terms of physico-chemical characteristics, descriptive statistics are the set of methods and techniques that allow us to present, describe and summarize, numerous and varied data; they allow us to know the characteristics of our sample.

For all variables, the standard deviation is more or less low, so the dispersion of the measurements around the mean is narrow. The results are therefore consistent, except for the last three variables, namely the $\mathrm{K} 2 \mathrm{O}, \mathrm{CaO}$ and $\mathrm{MgO}$ content, where the standard deviation is very high, which shows that there is a wide dispersion of the results for these contents (Table 5,6 and 7).

Table 5: Correlation between organic matter and soil mineral elements

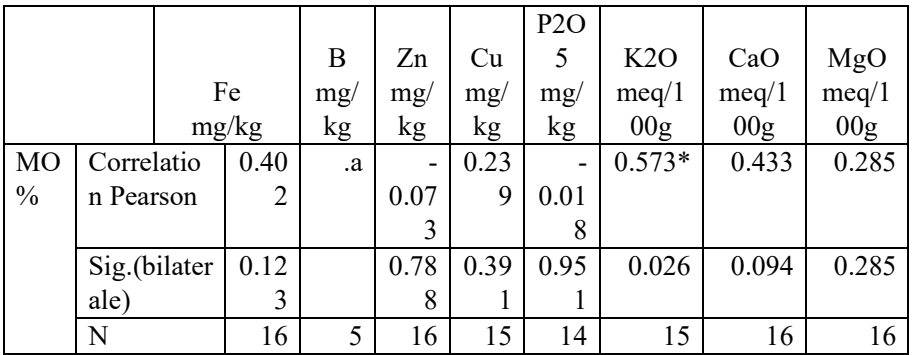

**The correlation is significant at the 0.01 level (bilateral).

*The correlation is significant at the 0.05 level (bilateral).

at. Calculation impossible because at least one variable is a constant

Table 6: Correlation between clay content and soil mineral elements

\begin{tabular}{|c|c|c|c|c|c|c|c|c|c|}
\hline \multicolumn{2}{|c|}{} & $\begin{array}{c}\mathrm{Fe} \\
\mathrm{mg} / \\
\mathrm{kg}\end{array}$ & $\begin{array}{c}\mathrm{B} \\
\mathrm{mg} / \\
\mathrm{kg}\end{array}$ & $\begin{array}{c}\mathrm{Zn} \\
\mathrm{mg} / \\
\mathrm{kg}\end{array}$ & $\begin{array}{c}\mathrm{Cu} \\
\mathrm{mg} / \\
\mathrm{kg}\end{array}$ & $\begin{array}{c}\mathrm{P} 2 \mathrm{O} \\
5 \\
\mathrm{mg} / \\
\mathrm{kg}\end{array}$ & $\begin{array}{c}\mathrm{K} 2 \mathrm{O} \\
\mathrm{meq} / 1 \\
00 \mathrm{~g}\end{array}$ & $\begin{array}{c}\mathrm{CaO} \\
\mathrm{meq} / 1 \\
00 \mathrm{~g}\end{array}$ & $\begin{array}{c}\mathrm{MgO} \\
\mathrm{meq} / 1 \\
00 \mathrm{~g}\end{array}$ \\
\hline $\begin{array}{c}\text { Arg } \\
\%\end{array}$ & $\begin{array}{c}\text { Correlati } \\
\text { on } \\
\text { Pearson }\end{array}$ & $\begin{array}{c}0.14 \\
2\end{array}$ &. $\mathrm{a}$ & $\begin{array}{c}0.10 \\
8\end{array}$ & $\begin{array}{c}0.13 \\
5\end{array}$ & $\begin{array}{c}- \\
0.05 \\
4\end{array}$ & -0.329 & 0.369 & -0.312 \\
\cline { 2 - 10 } & $\begin{array}{c}\text { Sig.(bilat } \\
\text { eral) }\end{array}$ & $\begin{array}{c}0.57 \\
5\end{array}$ & & $\begin{array}{c}0.67 \\
1\end{array}$ & $\begin{array}{c}0.60 \\
5\end{array}$ & $\begin{array}{c}0.85 \\
0\end{array}$ & 0.197 & 0.132 & 0.207 \\
\cline { 2 - 10 } & $\mathrm{N}$ & 18 & 6 & 18 & 17 & 15 & 17 & 18 & 18 \\
\hline
\end{tabular}

**The correlation is significant at the 0.01 level (bilateral).

*The correlation is significant at the 0.05 level (bilateral).

at. Calculation impossible because at least one variable is a constant.

Table 7: Correlation between $\mathrm{CaCO} 3$ content and soil mineral elements

\begin{tabular}{|c|c|c|c|c|c|c|c|c|c|}
\hline & $\begin{array}{c}\mathrm{Fe} \\
\mathrm{mg} / \\
\mathrm{kg}\end{array}$ & $\begin{array}{c}\mathrm{B} \\
\mathrm{mg} / \\
\mathrm{kg}\end{array}$ & $\begin{array}{c}\mathrm{Zn} \\
\mathrm{mg} / \\
\mathrm{kg}\end{array}$ & $\begin{array}{c}\mathrm{Cu} \\
\mathrm{mg} / \\
\mathrm{kg}\end{array}$ & $\begin{array}{c}\mathrm{P} 2 \mathrm{O} \\
5 \\
\mathrm{mg} / \\
\mathrm{kg}\end{array}$ & $\begin{array}{c}\mathrm{K} 2 \mathrm{O} \\
\mathrm{meq} / 1 \\
00 \mathrm{~g}\end{array}$ & $\begin{array}{c}\mathrm{CaO} \\
\mathrm{meq} / 1 \\
00 \mathrm{~g}\end{array}$ & $\begin{array}{c}\mathrm{MgO} \\
\mathrm{meq} / 1 \\
00 \mathrm{~g}\end{array}$ \\
\hline \multirow{6}{*}{$\begin{array}{l}\mathrm{Ca} \\
\mathrm{CO} \\
3\end{array}$} & Correlatio & 0.22 & \multirow[t]{3}{*}{.a } & 0.37 & 0.37 & - & \multirow[t]{3}{*}{-0.010} & \multirow[t]{3}{*}{0.171} & \multirow[t]{3}{*}{0.321} \\
\hline & n Pearson & 4 & & 7 & 5 & 0.20 & & & \\
\hline & & & & & & & & & \\
\hline & Sig.(bilate & 0.37 & & 0.12 & 0.13 & 0.47 & 0.970 & 0.499 & 0.194 \\
\hline & ral) & 2 & & 3 & 8 & 3 & & & \\
\hline & $\mathrm{N}$ & 18 & 6 & 18 & 17 & 15 & 17 & 18 & 18 \\
\hline
\end{tabular}

**The correlation is significant at the 0.01 level (bilateral).

*The correlation is significant at the 0.05 level (bilateral).

at. Calculation impossible because at least one variable is a constant.

In order to study the relationship between the mineral element content and the $\mathrm{CaCO} 3, \mathrm{MO}$ and clay fraction, we calculated the Pearson correlation coefficient (Figure 2). The results show that there is no correlation between these mineral elements and the rate of $\mathrm{CaCO} 3$ and clay fraction. The results for the organic matter content show that the latter explains $57 \%(\mathrm{p}<0.05)$ of the variation in $\mathrm{K} 2 \mathrm{O}$ content.

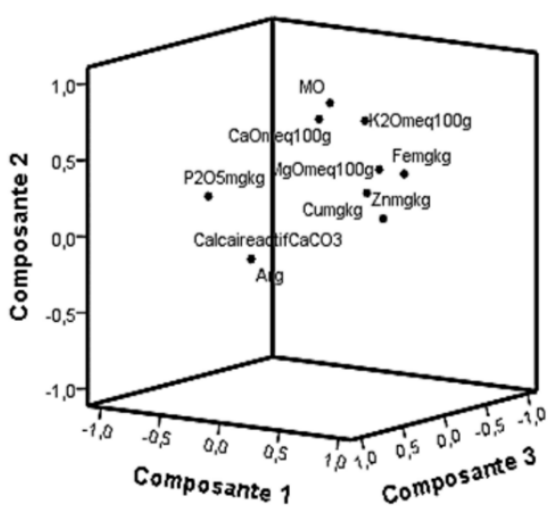

Figure 2: Principal component analysis of the physico-chemical properties of the soils sampled

The ANOVA test application, to compare the average characteristics of 19 sites (without distinction of depths) is presented in the table above. It shows that in the different sites studied, the difference in mean is insignificant for the parameters $\mathrm{pH}$, organic matter, $\mathrm{CaCO} 3$ content, clay content, $\mathrm{B}, \mathrm{CaO}$; it is also insignificant for the silt and sand variables, so the null hypothesis $\mathrm{HO}$ is accepted as long as there is no difference in the means. For the variables $\mathrm{Fe}, \mathrm{Zn}, \mathrm{Cu}, \mathrm{P} 2 \mathrm{O} 5, \mathrm{~K} 2 \mathrm{O}, \mathrm{MgO}$ the difference of the means is significant and, in this case, the null hypothesis H0 is rejected.

\subsection{Physico-chemical properties of apple leaf soil}

The differences in the average composition of the three varieties are shown in the table 8 . The apple leaf contains more $\mathrm{Na}$, $\mathrm{Cu}$ and zinc and less $\mathrm{Mg}, \mathrm{P}$ and $\mathrm{K}$. The coefficient of variation (CV) of the manganese content expressed as a percentage is much higher than that of the other elements, and the coefficient of variation $(\mathrm{CV})$ of the potassium content is the lowest, especially for magnesium and sodium the coefficient of variation is zero (Figure 3).

Table 8: Global apple leaf nutrient content statistics.

\begin{tabular}{|l|c|c|c|c|c|}
\hline & Average & $\begin{array}{c}\text { Standard } \\
\text { deviation }\end{array}$ & CV & Min & Max \\
\hline $\begin{array}{l}\text { Magnesium, Mg } \\
(\%)\end{array}$ & 0.1900 & 0 & 0 & 0.19 & 0.19 \\
\hline Phosphorus, P (\%) & 0.2200 & 0.01732 & 7.873 & 0.20 & 0.23 \\
\hline Potassium, K (\%) & 0.553333 & 0.0152753 & 2.761 & 0.5400 & 0.5700 \\
\hline Calcium, Ca (\%) & 1.4333 & 0.25580 & 17.846 & 1.19 & 1.70 \\
\hline $\begin{array}{l}\text { Manganese, Mn } \\
\text { (ppm) }\end{array}$ & 24.033 & 6.5577 & 27.286 & 20.0 & 31.6 \\
\hline Zinc, Zn (ppm & 32.733 & 6.0343461 & 18.435 & 25.8000 & 36.8000 \\
\hline Copper, Cu (ppm) & 129.33 & 12.662 & 9.790 & 118 & 143 \\
\hline Boron, B (ppm) & 26.333 & 2.5482 & 9.677 & 23.4 & 28.0 \\
\hline Sodium, Na (\%) & 249.00 & 0.000 & 0 & 249 & 249 \\
\hline
\end{tabular}




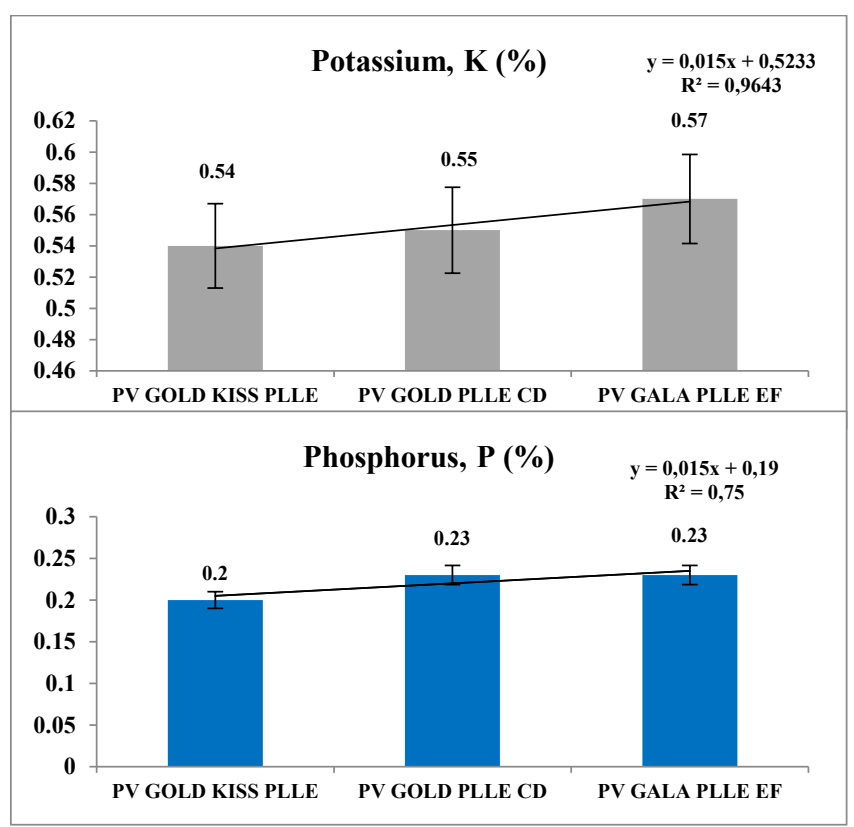

Figure 3: Phosphorus and potassium content in different apple varieties.

The differences in the average composition of the four varieties are shown in the table 9 and figure 4. Apple leaf contains more $\mathrm{Na}, \mathrm{Cu}$ and zinc and less $\mathrm{Mg}, \mathrm{P}$ and $\mathrm{K}$. The coefficient of variation $(\mathrm{CV})$ of the copper content expressed as a percentage is significantly higher than that of other elements, and the coefficient of variation $(\mathrm{CV})$ of boron content is the lowest.

Table 9: Global statistics on nutrient levels in apple fruit twigs.

\begin{tabular}{|l|c|c|c|c|c|}
\hline & Average & $\begin{array}{l}\text { Standard } \\
\text { Deviation }\end{array}$ & CV & Min & Max \\
\hline $\begin{array}{l}\text { Azote, N } \\
\text { (\%) }\end{array}$ & 0.42000 & 0.151217 & 36.004 & 0.2100 & 0.560 \\
\hline $\begin{array}{l}\text { Magnesium, } \\
\text { Mg (\%) }\end{array}$ & 0.612500 & 0.4090130 & 66.778 & 0.2500 & 1.100 \\
\hline $\begin{array}{l}\text { Phosphorus, } \\
\text { P (\%) }\end{array}$ & 0.060000 & 0.0529150 & 88.192 & 0.0100 & 0.130 \\
\hline $\begin{array}{l}\text { Potassium, } \\
\text { K (\%) }\end{array}$ & 2.4800 & 0.84573 & 34.102 & 1.31 & 3.26 \\
\hline $\begin{array}{l}\text { Calcium, Ca } \\
\text { (\%) }\end{array}$ & 1.8000 & 1.07316 & 59.620 & 0.60 & 3.10 \\
\hline $\begin{array}{l}\text { Manganese, } \\
\text { Mn (ppm) }\end{array}$ & 4.5100 & 1.98741 & 44.067 & 2.10 & 6.30 \\
\hline $\begin{array}{l}\text { Zinc, Zn } \\
\text { (ppm }\end{array}$ & 11.9675 & 7.93202 & 66.280 & 2.60 & 19.70 \\
\hline $\begin{array}{l}\text { Copper, Cu } \\
\text { (ppm) }\end{array}$ & 2.2225 & 2.05596 & 92.506 & 1.02 & 5.30 \\
\hline $\begin{array}{l}\text { Boron, B } \\
\text { (\%pm) }\end{array}$ & 4.9475 & 0.94026 & 19.005 & 4.12 & 6.30 \\
\hline Sodium, Na & 0.2100 & 0.07659 & 36.473 & 0.15 & 0.31 \\
\hline
\end{tabular}

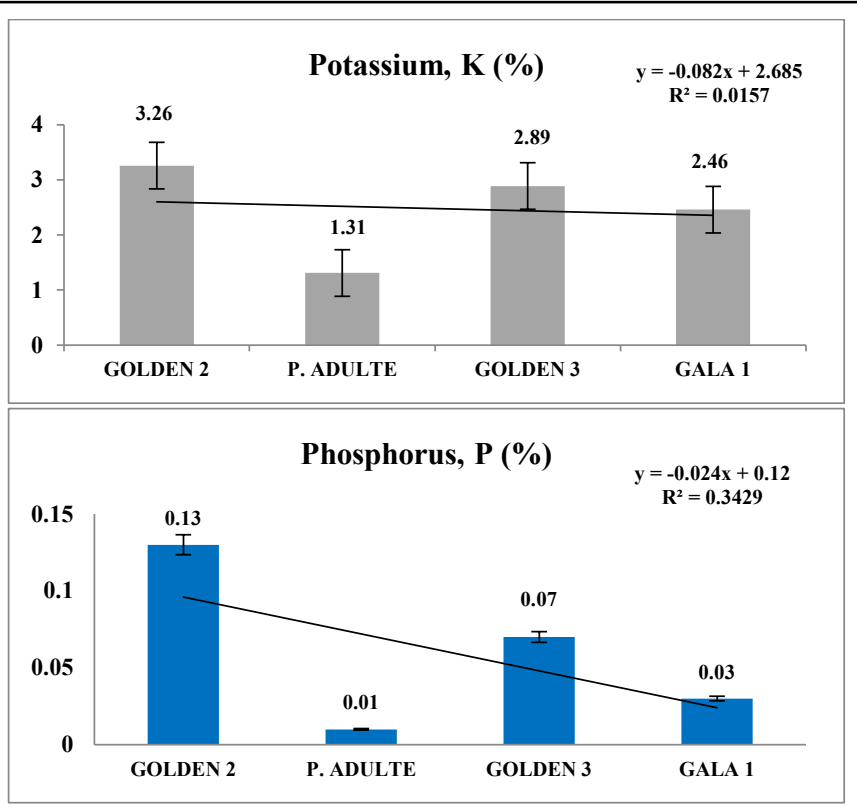

Figure 4: Phosphorus and potassium content in different varieties of apple fruit.

\section{Discussion}

The apple tree represents in Morocco an agricultural species of great importance. Growing apples requires a long period of vegetative rest to meet its cold needs; it also requires very specific conditions with regard to the various production factors, in particular for the soil / irrigation water combination. The main areas of apple plantations in Morocco are; Meknes, Midelt, Khenifra, Haouz Marrakech, Fes, Ouarzazate. Our study was carried in Beni Mellal-Khenifra region. The results of the granulometric analysis of the studied soils showed that the samples have a silty clay texture, which is often very favourable for apple tree cultivation. A good yield could therefore be obtained if the mineral elements provide the essential and important quantities for the good development of the crop. According to the literature review, the physicochemical properties of the soil play a major role in the yield of apples, in particular the $\mathrm{pH}[10,11]$. It should be noted that apple trees generally prefer slightly acidic soils with a pH between 6.5 and 6.8 [12]. However, the soil samples analyzed recorded rather average alkaline $\mathrm{pH}$ values of up to 8.85 . Despite the measured $\mathrm{pH}$, qualified as alkaline, the yields obtained on the farm are very satisfactory. Indeed, even if we often talk about an optimal $\mathrm{pH}$ for a particular plant, in fact the $\mathrm{pH}$ does not meet a physiological need of the plant. It is the action of $\mathrm{pH}$ on the physical, chemical and biological properties of the soil that creates a more favourable environment for mineral nutrition and plant growth. In fact, plants are most often able to cope with a $\mathrm{pH}$ difference of up to one unit. Most plants grow very well in soil with a $\mathrm{pH}$ of 6.5 [12]. Doucet in 2006 states that agricultural species that grow at $\mathrm{pH} 6$ most often prefer a $\mathrm{pH}$ of 6.5 and that all plants that grow in neutral soil with a $\mathrm{pH}$ of around 7 can tolerate a $\mathrm{pH}$ of 6.5 [13]. Regarding active limestone, apple tree fears soils with a high content of active limestone. This is not the case for our study soil with variable proportions which can sometimes be very high or even twice the tolerated standards. This can easily lead to iron deficiency. Furthermore, the more abundant the total $\mathrm{CaCO} 3$ rate in the soil, the greater the risk of blocking trace elements and phosphorus, hence the need to take these constraints into account 
when developing fertilization programs. For a good interpretation of the rate of organic matter, it is necessary to take into account the quantity, but also the quality of this organic matter, the ventilation, humidity and temperature conditions. According to the guide reasoned fertilization in fruit arboriculture, presented by the Chamber of Agriculture of Tarn-et-Garonn, the value of the desirable organic matter content according to a clay content $>30 \%$ must be between 2.5 and $3 \%$. However, the organic matter content in the present study is generally low, with contents varying between $0.48 \%$ and $3 \%$. Nevertheless, it is therefore necessary to add MO to the soil. As long as the OM content is high, the production potential of the soil is great. In addition, it will improve the physical properties (structure, porosity, water and air circulation, water retention capacity) and chemical (cation exchange capacity, reversible anionic bond, release of trace elements. by decomposition in the soil) [15]. Compared to the interpretation standards given by the INRA (National Institute of Agronomic Research) for Contribution to the establishment of standards of fertilization of apple trees in the Middle Atlas. According to Dr. Rachid Razouk (researcher, CRRA Meknes), the optimal levels of nutrients found in clay-loam soils (the case of the study) are classified as low for phosphorus, in the "sufficient" class for potassium and in the "high" class of $\mathrm{Ca}$ and $\mathrm{Mg}$ [16]. However, for $\mathrm{K} 2 \mathrm{O}$, the values found correspond in fact to the optimum intakes for a high apple yield. Internationally, experts agree that $1.5 \%$ is the theoretical critical limit, below which fertility declines rapidly. It is often desirable to aim to maintain a minimum rate of $2.5 \%$ and even 3.5 to $4 \%$ in heavy soils [13]. A similar study was carried out to assess the quality of agricultural soils in the northeastern area of the plain Tadla (Morocco).The results indicated that $1.12 \%$ of the study area has poor suitability for sustainable intensive agriculture due to their unsuitable texture and low salinity, while about $77 \%$ of cultivated soils are adapted to agricultural production [17]. According to Barakat et al, 2017 the diagnostic of the quality of agricultural land in Beni-Moussa, Tadla plain (Morocco), showed that about 1.69\% (1324.38 ha) of studied area are classified in the clas 'excellent suitable', 17.14\% (13449.81 ha) in 'good suitable', $75.70 \%$ (59393.30 ha) in 'medium suitable' and $5.47 \%$ (4293.11 ha) in 'poor suitable' for sustainable intensive agriculture. Reading the results of the leaf analysis and their comparison with international standards for the nutrient content of apple leaves shows that for the elements phosphorus, calcium and magnesium, their concentration levels in the leaves are too satisfactory. On the other hand, the nutrient potassium has levels in the leaves below the desired limits compared to the required reference standards. A slight potassium deficiency is probably due to excessive nitrogen fertilization, as nitrogen-induced vegetative growth generates high potassium requirements. In general, leaf levels of $\mathrm{N}, \mathrm{P}, \mathrm{K}, \mathrm{Ca}$, and $\mathrm{Mg}$ are significantly correlated with their levels in the soil. However, foliar analysis is an effective tool for assessing the nutritional status of trees and for readjusting fertilizer requirements taking into account factors that can affect nutrient availability and root uptake.

\section{Conclusion}

The soils studied and sampled at different depths $(0-60 \mathrm{~cm})$ have a clay-loam texture. They are relatively poor in organic matter, the content of organic matter and major elements are not sufficient to optimize the optimum yield of the apple tree culture.
The study shows a correlation between apple yield and nutrient content in the soil and leaves. The nutrient deficiencies observed can be corrected by the application of fertilization and adequate maintenance. However, further studies are needed to fully understand other variables such as the nature of rootstocks, the varieties cultivated and the method of irrigation which strongly influences apple tree production and yield. A prospect may be distant; indeed, it would be very interesting to generalize our paradigm to other sectors related to apple growing. As well as tackling research on phytosanitary techniques in order to move from the conventional vision to the integrated vision. Further research could also focus on other crops.

\section{References}

[1] R. Moussadek Impacts of conservation agriculture on the properties and productivity of vertisols in Central Morocco. Afrika focus. 25 (2) 147-151, 2012

[2] N. Akesbi. Evolution and perspectives of agriculture Moroccan. In Report 50 years of human development and perspectives for 2025. Casablanca. Maghrebi. 85-198, 2006.

[3] Agricultural credit in Morocco: Accessed on November 09, 2020. Available at: https://www.fellah-trade.com/fr/ plant-sector / technical-sheets / apple tree.

[4] P. Milleville, G. Serpantie. Agrarian dynamics and the question of the intensification of farming in the Sahelian and savanna zones of Africa. Accounts of the French Academy of Agriculture 80, 149-161, 1994.

[5] B. Diwediga, K. Hounkpe, K. Wala, K. Batawila, T. Tatoni, Akpagana, K. Off-season agriculture on the banks of the oti and its tributaries. African Crop Sci. J. 20, 613-624, 2012.

[6] R. Moussadek. Impacts of conservation agriculture on the properties and productivity of vertisols in Central Morocco. Afrika focus. 25(2), 147-151, 2012.

[7] Regional Directorate of Agriculture of Beni Mellal-Khenifra, agricultural monograph of the Beni Mellal-Khenifra region. 2016. Accessed on March 26, 2020.

[8] P. Martin -Prevel, J. Gagnard, P. Gautier. Plant analysis in the control of the diet of temperate and tropical plants. 131, 1984

[9] A. Finigue. Water resources in the direction of the Beni Mellal Atlas: management issues and local development. 2018. University of Angers Doctoral School DEGEST Angers Thesis. Accessed on March 26, 2020. Available on https://tel.archives-ouvertes.fr/tel-01708289/document.

[10] Ministry of Agriculture and Maritime Fisheries. Technology transfer in agriculture. 2008. Consulted on March 26, 2020. Available at https://www.agrimaroc.net/bulletins/btta_165.pdf.

[11] K. Aggelopoulou, D. Wulfsohn, S. Fountas, G. Nanos, T. Gemtos, S. Blackmore. Spatial variability of yield and quality in an apple orchard. Precision Agriculture 11(5), 538-556, 2010.

[12] K. Aggelopoulou, S. Fountas, D. Pateras, G. Nanos, Gemtos, T. Soil spatial variability and site-specific fertilization maps in an apple orchard. Precision Agriculture 12(1), 118-12, 2011.

[13] K. Pontikis, Applied Pomology. Stamoulis Publications, Athens, Greece, 74.

[14] R. Doucet. Climate and agricultural soils. ed. Berger, Eastman, Quebec. xv, 443, 2003.

[15] Tarn and Garonne. Chamber of Agriculture. Guide To Reasoned Fertilization In Fruit Arboriculture. 2019. Accessed March 27, 2020. Available at: [https://mag.inrameknes.info/? P $=1400$.

[16] R. Razouk Contribution to the establishment of apple tree fertilization standards in the Middle Atlas. 2018. Accessed March 27, 2020. Available at: https://mag.inrameknes.info/?p=1400.

[17] W. Ennaji, A. Barakat, M. El Baghdadi, H. Oumenskou, M. Aadraoui, L. A Karroum, \& A. Hilali. GIS-based multi-criteria land suitability analysis for sustainable agriculture in the northeast area of Tadla plain (Morocco). Journal of Earth System Science, 127(6), 79, 2018.

[18] A. Barakat, W. Ennaji, A. El Jazouli, R. Amediaz, \& F. Touhami. Multivariate analysis and GIS-based soil suitability diagnosis for sustainable intensive agriculture in Beni-Moussa irrigated subperimeter (Tadla plain, Morocco). Modeling Earth Systems and Environment, 3(1), 3, 2017. 